\title{
Activation of Clones Producing Self-reactive Antibodies by Foreign Antigen and Antiidiotype Antibody Carrying the Internal Image of the Antigen
}

\author{
N. C. Bailey, V. Fidanza, R. Mayer, G. Mazza, M. Fougereau, and C. Bona \\ Department of Microbiology, Mount Sinai School of Medicine, New York 10029; Centre d'Immunologie, Marseille-Luminy, France
}

\begin{abstract}
Because we found in previous work that a high fraction of antibodies exhibiting various specificities bound to glutamic acid ${ }^{50}$-tyrosine ${ }^{50}$ homopolymer (GT) and expressed pGAT cross-reactive idiotype (IdX), we studied the activation of clones producing multireactive antibodies in 1-mo-old MRL/ lpr and $\mathrm{C}_{3} \mathrm{H} / \mathrm{HeJ}$ mice bearing $\mathrm{VH}^{\mathrm{J}}$ haplotype. The activation of such clones was studied after mice were immunized with GT in CFA, HP20 (an anti-Id MAb carrying the internal image of GT in the D region), and a synthetic peptide corresponding to the D segment of HP20.

Our results indicate that immunized mice produced both GT- and self-reactive antibodies. Study of the immunochemical properties of MAb showed that they exhibit multispecific properties and bind with similar-affinity constants to GT or self-antigens such as DNA, Smith antigen (Sm), and IgG $_{2}$ a. An important fraction of antibodies obtained from MRL/lpr mice immunized with HP20 expressed pGAT IdX and some of these antibodies share IdX expressed on anti-DNA, Sm, and rheumatoid factor (RFs) antibodies. The hybridomas producing multispecific autoantibodies use heavy-chain- (VH) and lightchain-variable region (VK) genes from various $V$ gene families, suggesting that they do not derive from the pool of GAT precursors. Sequencing of $\mathrm{VH}$ and $\mathrm{VK}$ genes of two antibodies show that they can use closely related VHJ558, unmutated VK1, or different VK genes than those used by anti-GT antibodies.

Our data demonstrate that clones producing antibodies binding to GT and self-antigens with similar-affinity constants can be activated by foreign or anti-Id antibodies carrying the internal image of the antigen or even by a synthetic peptide corresponding to the D segment of anti-Id antibodies.
\end{abstract}

\section{Introduction}

There are numerous reports demonstrating that antibodies specific for foreign antigens exhibit binding to self-antigens (1, 2 ). The interaction of foreign antigens with clones producing autoantibodies may play a significant role in the breaking of self-tolerance, a process that could contribute to the occurrence of autoimmune phenomena.

Address reprint requests to Dr. C. Bona, Department of Microbiology, Annenberg Building 16-60, Mount Sinai School of Medicine, Box 1124, 1 Gustave Levy Place, New York 10029.

Received for publication 30 December 1988 and in revised form 5 April 1989

J. Clin. Invest.

(c) The American Society for Clinical Investigation, Inc.

0021-9738/89/09/0744/13 $\$ 2.00$

Volume 84, September 1989, 744-756
For a long time it has been known that antibodies reacting with heart tissue (3), brain (4), and skeletal muscles (5) are detected in patients with acute rheumatic fever. It was recently demonstrated that MAbs specific for Staphylococcus pyogenes $M$ type 5 obtained from BALB/c mice also bind muscle proteins (6).

In a previous study we demonstrated that 8 of 20 heavychain-variable region (VH) ${ }^{1} \mathrm{~J}_{558^{+}}$monoclonal autoantibodies with various specificities also interacted with foreign antigens known to bind to antibodies encoded by genes derived from the VH J558 family. Such antibodies bound to glutamic acid-tyrosine (GT), glutamic acid-phenylalanine homopolymers, phenylarsonate, lysozyme, and polysaccharides of Escherichia coli and $S$. providenciae. We also found that an important fraction of such autoantibodies share the cross-reactive idiotypes of $\mathrm{VHJ}^{258^{+}}$antibodies specific for foreign antigens such as $\alpha 1-3$ dextran (J558), arsonate (CRI), influenza virus (PY206), and GAT (pGAT) (7).

Based on these data, we began to investigate the activation of autoreactive clones by GT as well as by an anti-Id antibody carrying the internal image of the antigen.

The choice of GT versus a more physiological antigen was based on the following: $(a)$ the fundamental question of whether a self-reactive clone can be activated by a foreign antigen; $(b)$ that GT is a chemically well-defined antigen eliciting an immune response under Ir gene control (8); and (c) in the GT system, we possess an anti-Id MAb that carries the internal image of the antigen defined by a structural correlate (9) the best criterion to define Ab2 $\beta$. Only two anti-Id antibodies, one in the GT system and the other in the reovirus system (10), were defined by both structural and physiological criteria as being of the $A b 2 \beta$ type.

Because we previously found that MRL monoclonal RFs, anti-DNA, or Smith antigen (Sm) antibodies bind to GT and share cGAT-IdX, we chose MRL/lpr mice to conduct these experiments because it is known that the precursors of clones producing autoantibodies specific for these self-antigens are activated during the florid phase of the autoimmune disease developed in MRL/lpr.

Our data show that immunization with GT or anti-Id antibodies carrying the internal image of GT activates clones producing antibodies that bind to GT and to self-antigens. Some of these antibodies share the idiotopes of both anti-GT antibodies and RFs, anti-DNA, and Sm antibodies. Although some of these antibodies use genes derived from the same variable region (V) germline as anti-GT antibodies, others use completely different $\mathrm{V}$ genes.

1. Abbreviations used in this paper: $\mathrm{Ab} 2 \beta$, anti-idiotype antibody carrying the internal image of the antigen; $C D R$, complementary determining region; GT, glutamic acid ${ }^{50}$-tyrosine ${ }^{50}$ homopolymer; IdX, cross-reactive idiotype; Sm, Smith antigen; $\mathrm{VH}$, heavy-chain variable region; VK, light-chain variable region; $\mathrm{V}$, variable region. 


\section{Methods}

\section{Animals}

2-wk-old MRL/lpr and $\mathrm{C} 3 \mathrm{H} / \mathrm{HeJ}$ mice were purchased from Jackson Laboratory, Bar Harbor, ME.

\section{Antigens}

Glutamic acid ${ }^{50}$ tyrosine ${ }^{50}$ homopolymer (GT) was a gift from Dr. P. Maurer (Jefferson University, Philadelphia, PA) and Sm antigen was a gift from Dr. H. Dang (University of Texas, San Antonio, TX). Salmon sperm DNA was acquired from Sigma Chemical Co. (St. Louis, MO). HOPC1 (G2a $\lambda)$ was purified from ascitic fluid on protein A-Sepharose (Pharmacia Fine Chemicals, Piscataway, NJ) column.

\section{Antiidiotype antibodies}

HP20 is a MAb specific for cGAT-IdX borne by G5 Bb2.2 (G5) an anti-GT antibody. Chromatographically purified rabbit anti-Id idiotype antibodies specific for LPS, 10-1, a BALB/c monoclonal RF; Y-2, a MRL anti-Sm; and H130, a MRL anti-DNA MAb, were used in these experiments. 63-4 is a syngeneic MAb specific for PY203, a BALB/c anti-HP of PR8 (HINI) influenza virus. The specificity of these anti-Id antibodies was previously described $(7,11)$.

\section{Préparation of hybridomas and purification of $M A$ Abs}

Hybridomas were prepared by fusion of splenic lymphocytes with Sp2/0 according to a previously described technique (12). Positive hybridomas cloned under stringent limiting dilution conditions $(0.5$ cell/well) were expanded in culture.

Antibodies from culture supernatant were purified on a rat antimurine K-Sepharose 4B column.

\section{Measurement of concentration of antibodies}

The concentration of antibodies in the sera of mice immunized with CFA, G'T, or anti-Id antibodies was measured by RIA. Microtiter plates were coated overnight at $4^{\circ} \mathrm{C}$ with antigen: $10 \mu \mathrm{g} / \mathrm{ml}, \mathrm{GT}, 10$ $\mu \mathrm{g} / \mathrm{ml} \mathrm{HOPCl}\left(\mathrm{IgG} 2 \mathrm{a}, \lambda\right.$ ) heated for 15 minutes at $56^{\circ} \mathrm{C} ; 1 \mu \mathrm{g} / \mathrm{ml} \mathrm{Sm}$, or polyarginine and DNA as previously described (7).

After being washed and postcoated with PBS-BSA, the plates were incubated for $2 \mathrm{~h}$ with various dilution of sera $(1: 10-3,000)$ in BSAPBS-Tween. After being washed extensively, plates were incubated for $2 \mathrm{~h}$ at room temperature with ${ }^{125} \mathrm{I}$-labeled rat anti-mouse $\mathrm{K}$ antibody $(50,000 \mathrm{cpm} /$ well). The concentration of antibody was determined by using an interpolating computer program and standard curves constructed with MAbs specific for GT(G5), DNA(HB2), Sm (Y-2), and RF (MRL55-18).

\section{Binding of MAbs to Ags}

The binding of MAbs to GT, DNA, Sm, and IgG2a was determined using the same type of RIA as described above for the measurements of antibody concentrations. Specificity of the binding was determined by using a competitive inhibition RIA. This technique was carried out in two steps: $(a)$ in liquid phase, $0.5 \mu \mathrm{g}$ of antibodies were incubated with various amounts of antigen (0.1-10 $\mu \mathrm{g})$ for $2 \mathrm{~h}$ at room temperature in microtubes coated previously with BSA; and $(b) 50 \mu$ l of this mixture was transferred to microplates previously coated with antigens as described above.

\section{Affinity measurement}

This was done according to Friguet et al. (13). Briefly, in a preliminary experiment, each antibody, at various concentrations, was incubated for different lengths of time in microtiter plates coated with antigens. The content of each well was transferred into another coated well and incubated at the same time. In the two series of wells, the bound antibody was revealed using ${ }^{125} \mathrm{I}$-labeled anti-K as described before. This pilot experiment was performed to establish that no readjustment of the equilibrium in the liquid phase would occur during the affinity measurement. We considered a time period to be satisfactory when the binding in the second set of wells was not $<85 \%$ of the binding observed with the first set. The affinity was measured using an RIA similar to the one described previously. Ab at a known concentration was incubated overnight with various amounts of Ags in PBS-BSA. The $\mathrm{Ab}-\mathrm{Ag}$ mixture was then transferred into antigen-coated wells incubated for the time determined in the preliminary experiment. The binding was determined by ${ }^{125} \mathrm{I}$-anti-K MAb. The calculation of the affinity was performed according to Friquet et al. (13) and the $K_{\mathrm{a}}$ is expressed in grams/liter instead of molar/c because of the nature of the source of the antigens used (varying molecular weight and heterogeneity of polymers) (14).

\section{Study of idiotypy}

Four idiotypic systems were used in this study defining cross-reactive idiotypes on GT-specific antibodies and of autoantibodies specific for DNA, Sm, and RFs. (a) IdX of GT antibodies. HP20 is an anti-Id MAb recognizing an IdX expressed on G5, an MAb specific for the GAT terpolymer. (b) IdX of anti-DNA antibodies. H130 is an anti-DNA MAb obtained from MRL/lpr mice and 108 is an anti-Id MAb against H130. (c) IdX of anti-Sm antibodies. Anti-Y-2 is a rabbit anti-Id antibody raised against $\mathrm{Y} 2$, an anti-Sm MAb obtained from an MRL/lpr mouse. (d) IdX of RF. Y19-10 anti-LPS 10-1 defines a cross-reactive idiotype recognized by polyclonal rabbit antibodies produced by immunization with LPS 10-1, which is a BALB/c MAb exhibiting RF activity. Rabbit antibodies recognize an IdX on Y 19-10, a monoclonal RF obtained from BALB/c mouse immunized with Yersinia enterocolitica. These idiotypic systems have been described in detail previously (7). Presence of cross-reactive idiotypes was determined by a competitive inhibition RIA as previously described (7). G5IdX was determined by a sensitive sandwich assay as previously described (15).

\section{Molecular techniques}

Extraction of RNA and Northern blotting. RNA was extracted from 3-5 $\times 10^{7}$ cells using the guanidinium-thiocyanate method according to a method previously described (16). Northern blotting was performed by electrophoretically fractionating the RNA on a $1.2 \%$ agarose gel ( $6 \%$ formaldehyde) in $40 \mathrm{mM} 4$-morpholino propane sulfonic acid, $20 \mathrm{mM} \mathrm{NaOAc}$ and $2 \mathrm{mM}$ EDTA. The gel was blotted overnight onto nitrocellulose using $20 \times$ SSC. Blots were baked in a vacuum oven for $2 \mathrm{~h}$ at $80^{\circ} \mathrm{C}$.

Prehybridization was carried out at $42^{\circ} \mathrm{C}$ in $50 \%$ formamide, $5 \times$ $\operatorname{SSPE}\left(20 \times=2.4 \mathrm{M} \mathrm{Nacl}, 0.3 \mathrm{M}\right.$ sodium citrate, $0.2 \mathrm{M} \mathrm{KH}_{2} \mathrm{PO}_{4}, 0.02$ $M$ EDTA), $5 \times$ Denhardt's, $50 \mu \mathrm{g} / \mathrm{ml}$ sheared denatured salmon sperm DNA. Probe was added at $2 \times 10^{6} \mathrm{cpm} / \mathrm{ml}$ in hybridization solution ( $50 \%$ formamide, $5 \times$ SSPE, $1 \times$ Denhardt's, $100 \mu \mathrm{g} / \mathrm{ml}$ salmon sperm DNA, and $10 \%$ dextran sulfate). Blots were hybridized overnight at $42^{\circ} \mathrm{C}$, then washed two times for $15 \mathrm{~min}$ in $2 \times \mathrm{SSC}, 0.1 \% \mathrm{SDS}$ at $68^{\circ} \mathrm{C}$, then two times in $0.1 \times \mathrm{SSC}$ and $0.1 \%$ SDS for $15 \mathrm{~min}$ at $68^{\circ} \mathrm{C}$, and autoradiographed on Kodak XAR film and intensifying screens at $-70^{\circ} \mathrm{C}$ for a few days. The background was reduced by rewashing the blots with proteinase $\mathrm{K}$ in buffer (16).

$V$ gene probes. The VH gene family probes (VHX24, VH36-60, VH36-09, VHJ606, VHJ558, VHS107, VHQPC52, and VH7183) and VK gene family probes (VK1, VK2, VK4, VK8, VK9, VK10, VK19, VK21, VK29, and VK24) were prepared as described elsewhere (17). Probes were prepared according to standard technique (16). The preparation of the Lyl probe was carried out as previously described (18).

Nucleotide sequence. RNA from GP138-10 and H45-5 hybridomas was prepared as above and CDNA was synthesized using a kit manufactured by Amersham Corp. (Arlington Heights, IL). Tailing of cDNA $3^{\prime}$ ends with dCTP, annealing with d6-tailed pUCB (Pharmacia Fine Chemicals) and transfection of $\mathrm{dH} 5 \mathrm{~d}$ bacteria were done according to Sikder et al. (19). Screening and selection of transformants and preparation was according to standard techniques (16) sequencing of double standard plasmid DNA with sequenase was performed using the Sanger method (20). Searching of Nucleotide Sequence Data Base 1 and sequence comparison and analysis was assisted by computer software described in reference 21 . 


\section{Results}

(a) Synthesis of autoantibodies by animals immunized with GT or HP20. As we demonstrated in previous experiments, autoantibodies from MRL/lpr mice bound to GT and shared the idiotopes of G5, an anti-GAT antibody. Based on this observation, we studied the in vivo significance of this particular binding specificity, namely, the effect of GT immunization on the production of autoantibodies. In the same experiments, we studied the effect of the immunization with HP20, an antiId antibody that carries the internal image of GT, and of 63-4 monoclonal anti-Id specific for HA of influenza virus-specific antibodies.

These experiments were carried out on 1-mo-old MRL/lpr and $\mathrm{C}_{3} \mathrm{H} / \mathrm{HeJ}$ mice bearing the same $\mathrm{VH}^{\mathrm{J}}$ haplotype. We chose $\mathrm{MRL} / \mathrm{lpr}$ mice, because it is known that they have the precursors of clones producing autoantibodies specific for DNA, Sm and RFs that are expanded in 3-mo-old mice.

The data depicted in Fig. 1 show that 1-mo-old MRL/lpr mice injected with saline do not produce significant amounts of autoantibodies during a 3-wk period.

A slight increase of autoantibody production was observed in mice injected with CFA, which probably is related to polyclonal activators contained in mycobacteria cell wall. Both $\mathrm{MRL} / \mathrm{lpr}$ and $\mathrm{C}_{3} \mathrm{H} / \mathrm{HeJ}$ mouse strains injected with $50 \mu \mathrm{g} \mathrm{GT}$ in CFA produced anti-GT antibodies. GT immunized mice produced RF, which is not surprising based on data that demonstrated that the immunization with $\mathrm{T}$-dependent antigens is associated with RF production in normal strains (22) as well as those prone to autoimmune disease (23). Interestingly, a significant increased concentration of anti-DNA and Sm antibodies was detected in GT-immunized MRL/lpr mice.

Immunization of mice three times during a 2-wk period with $50 \mu \mathrm{g}$ HP20 in saline caused a significant increase of anti-GT antibodies in both mouse strains. This confirms that $\mathrm{HP} 20$ is a true $\mathrm{Ab} 2 \beta$ bearing GT sequence in D region, function as an antigen. The immunization with HP20 elicited not only the production of anti-GT antibodies but also autoantibodies (Fig. 1). No increased concentration of anti-GT antibodies or autoantibodies were observed in the animals injected with saline or 63-4 anti-Id MAb.

These data clearly show that immunization with GT or $\mathrm{Ab} 2 \beta$ activates clones that produce self-reactive antibodies. This effect can be related to either activation of autoreactive clones through an idiotypic cross-regulation mechanism of parallel sets (15) or alternatively by activation of clones producing multispecific antibodies.

(b) Frequency of hybridomas producing multireactive antibodies prepared from animals immunized with GT or HP20. Due to the quantitative limitations of serum samples used to carry out absorption experiments on four antigen immunoadsorbants, and to study possible multibinding properties of antibodies produced subsequent to immunization with GT or HP20, we have prepared hybridomas from these mice.

Hybridomas have been prepared from 1-mo-old MRL/lpr or $\mathrm{C}_{3} \mathrm{H} / \mathrm{HeJ}$ mice after completion of immunization with $\mathrm{GT}$ or anti-Id MAbs HP20 and 63-4. The hybridomas from animals immunized with GT were initially screened by using an RIA technique for GT binding and the positive ones were further selected for binding to self-antigens. The hybridomas obtained from animals immunized with anti-Id antibodies were screened for binding to GT and self antigens.

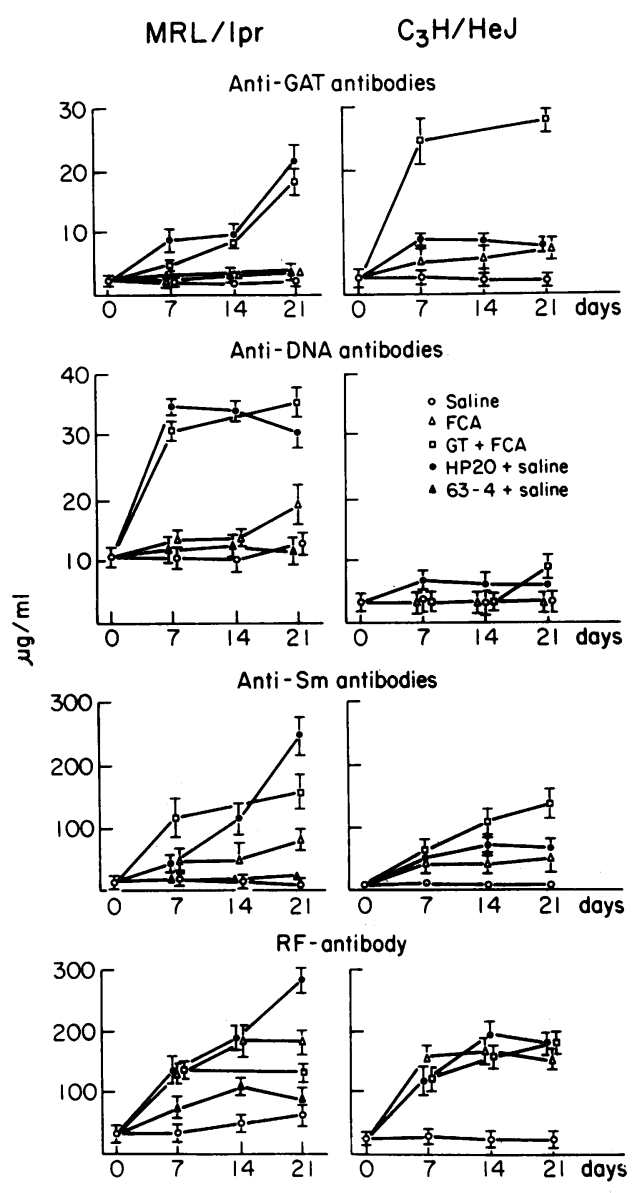

Figure 1. Kinetics of occurrence of anti-GAT, DNA, Sm, and RF antibodies in 1-mo-old MRL/lpr and $\mathrm{C}_{3} \mathrm{H} / \mathrm{HeJ}$ mice injected with 0.2-ml saline or CFA or immunized with GT in CFA or HP20 or 63-4 anti-Id MAbs in saline. The results represent average of concentration of antibodies (in micrograms/milliliter) \pm SD of a group of five mice.

After selection, the hybridomas were cloned and retested for antigen binding activity. Positive clones were expanded in culture and antibodies were purified from suppernatant on antimurine $\mathrm{K}$ antibody-Sepharose 4B column.

From 1-mo-old MRL/lpr mice immunized 2 wk before fusion with CFA $(0.2 \mathrm{ml}), 146$ hybridomas were obtained (designated FM series) and only one exhibited self reactivity.

From 1-mo-old MRL/lpr mice immunized $6 \mathrm{~d}$ before fusion with GT in CFA (primary response), 694 hybridomas were obtained (designated GP series). Four hybridomas exhibited binding activity to GT and self-antigen and one only to self-antigens.

From 1-mo-old mice immunized $14 \mathrm{~d}$ previoúsly with GT in CFA and $6 \mathrm{~d}$ before fusion with GT in saline (secondary response) (designated GS series for MRL/lpr and CGS series for $\mathrm{C}_{3} \mathrm{H} / \mathrm{HeJ}$ mice) 436 hybridomas were obtained from MRL and 192 from $\mathrm{C}_{3} \mathrm{H} / \mathrm{HeJ}$. Four hybridomas from these mice exhibited self reactivity.

From 1-mo-old mice immunized three times with antiidiotype antibodies in saline hybridomas were obtained.

From MRL/lpr mice immunized with HP20 antibodies 370 hybridomas (designated $\mathrm{H}$ series) were obtained, six exhibited multispecific binding activity and three exhibited self-re- 
activity. From 120 hybridomas obtained from MRL/lpr mice immunized with 63-4 antibody (designated 63 series), only two antibodies exhibited self-reactivity.

From 210 hybridomas obtained from $\mathrm{C}_{3} \mathrm{H} / \mathrm{HeJ}$ mice immunized with HP20 (designated $\mathrm{CH}$ series) two bound to GT and self-antigens and four to only self-antigens (see Table I).

From these data it appears that a high frequency of hybridomas producing GT and self-reactive antibodies were observed in animals prone to autoimmune disease and normal animals immunized with HP20 and from GT primed MRL/lpr mice. It should be mentioned that the majority of hybridomas producing GT antibodies from secondary GT response are devoid of self-binding activity.

(c) Antigen binding properties of multireactive MAbs. Antigen binding specificity of MAbs was studied by RIA in which microtiter plates coated with antigen were incubated with various amounts of antibodies (1-30 $\mu \mathrm{g})$ and then with ${ }^{125} \mathrm{I}$-antimurine K MAb.

The data depicted in Fig. 2 show the binding activities obtained from MRL/lpr mice. One antibody obtained from animals immunized with CFA (FM35-4) showed a significant binding to dsDNA. Five antibodies obtained from GT primary response exhibit the following binding properties: three bound to GT and to autoantigens (GP88, GP99-5, and GP133), one to GT, Sm, and DNA (GP138-10) and one displayed a weak binding to GT, but significant binding to DNA (GP75-9). From GT secondary response, two antibodies (GS4-1 and GS1 1-1) bound to all four antigens tested, whereas GS13-1 was a "sticky" antibody. Among antibodies obtained from animals immunized with HP20 antiidiotype antibody, five exhibited binding activity to GT and to one or several self-antigens (H45-5, H16-5 H127-1, H4-2, and H8-1) and three only exhibited binding to self-antigens (H17-1, H113-1, and H91-16).

Two antibodies from MRL/lpr mice immunized with 63-4 MAbs exhibited significant binding to ds DNA only. A single MAb from GT secondary response of $\mathrm{C}_{3} \mathrm{H} / \mathrm{HeJ}$ mice (CGS21-
17) exhibited binding to Sm and DNA. Six antibodies were obtained from $\mathrm{C}_{3} \mathrm{H} / \mathrm{HeJ}$ immunized with $\mathrm{HP} 20$. Two antibodies (CH154-1 and CH46-1) exhibited binding to GT, DNA, $\mathrm{Sm}$, and G2a, whereas four (CH1 13-1, CH24,10 CH55-8, and CH154-1) showed a strong binding to DNA (Fig. 3).

We also studied the binding activity to self-antigens of 1B5-D7-F10, a GAT-specific MAb elicited by the immunization of BALB/c mice with a synthetic peptide corresponding to $D$ region of Ab2 $\beta$ (Lys-Lys-Ala-Arg-Pro-Leu-Tyr-Phe-ArgHis-Asp-Glu-Glu-Tyr-Tyr) coupled with BSA (24). The data illustrated in Fig. 4 show that this MAb exhibited significant binding activity to DNA, Sm, and G2a. The binding of MAbs to antigens was inhibited in various degree by GT as well as by self-antigens (data not shown). To obtain more precise information on the interaction of the antibodies with the antigens we measured the $K_{\mathrm{a}}$ for GT and self-antigens of GP and $\mathrm{H}$ series of multireactive antibodies obtained from MRL/lpr mice. The data presented in Table II show that all these antibodies have a moderate $K_{\mathrm{a}}$ for both foreign and self antigens. Whereas GP138-10, GP99-5, H8-1, H4-2, and H45-5 showed one $\log$ higher affinity for GT than self-antigens, GP133, GP88, and H16-5 showed a higher affinity for self antigens compared with GT.

These results suggest that the clones producing multispecific antibodies subsequent to immunization with GT or $A b 2 \beta$ belong to primary GT repertoire characterized by Ig receptors with moderate affinity for the antigen.

These data strongly suggest that autoreactive clones can be activated in normal or animals prone to autoimmune diseases by a foreign antigen or an $\mathrm{Ab} 2 \beta$. This observation implies that the Ig receptor of such clones should have reasonably high affinity for GT to bind the antigen and to deliver an activation signal.

(d) Study of the expression of cross-reactive idiotype on multispecific antibodies. Previous studies showed that G5IdX is expressed on the majority of anti-GAT antibodies that bind

Table I. Frequency of Self-reactive Hybridoma MAbs Obtained from MRL/lpr and $C_{3} H / H e J$ Mice

\begin{tabular}{|c|c|c|c|c|}
\hline \multirow[b]{2}{*}{ Origin of hybridomas } & \multirow{2}{*}{$\begin{array}{l}\text { No. of hybridomas } \\
\text { obtained }\end{array}$} & \multicolumn{3}{|c|}{ Binding specificity } \\
\hline & & GT & GT + self-antigen & Self-antigen \\
\hline MRL injected with CFA & $146(1)$ & 0 & 0 & $\begin{array}{c}1 \\
(\text { FM35-4) }\end{array}$ \\
\hline MRL immunized with $1 \times$ GT (primary) & $694(2)$ & 5 & $\begin{array}{c}4 \\
\text { (GP138-10, GP99-5, GP88, GP133) }\end{array}$ & $\begin{array}{c}1 \\
(\text { GP75-9) }\end{array}$ \\
\hline MRL immunized with $2 \times$ GT (secondary) & $436(2)$ & 7 & $\left(G S 11-1\right.$, GS4-1) ${ }^{2}$ & $\begin{array}{c}1 \\
(G S 13-1)\end{array}$ \\
\hline MRL immunized with $3 \times$ HP20 & $370(3)$ & 2 & $\begin{array}{c}7 \\
\text { (H8-1, H16-5, H4-2, H45-5, H113-1, } \\
\text { H164-4, H127-1) }\end{array}$ & $\begin{array}{r}2 \\
1 \\
(\mathrm{H} 17-1, \mathrm{H} 81-16)\end{array}$ \\
\hline $\begin{array}{l}\text { MRL immunized } \\
3 \times 63-4\end{array}$ & $120(1)$ & 0 & 0 & $\begin{array}{c}2 \\
(63-86-7,63-99-7)\end{array}$ \\
\hline $\begin{array}{l}\mathrm{C}_{3} \mathrm{H} / \mathrm{HeJ} \text { immunized } \\
2 \times \mathrm{GT}\end{array}$ & $192(1)$ & 9 & 0 & $\begin{array}{c}1 \\
(C G 21-17)\end{array}$ \\
\hline $\begin{array}{l}\mathrm{C}_{3} \mathrm{H} / \mathrm{HeJ} \text { immunized } \\
3 \times \mathrm{HP} 20\end{array}$ & $210(2)$ & 3 & $\begin{array}{c}2 \\
(\mathrm{CH} 154-1, \mathrm{CH} 113-1)\end{array}$ & $\begin{array}{l}\stackrel{4}{(\mathrm{CH} 24-10, \mathrm{CH} 46-1, \mathrm{CH} 44-7,} \\
\text { CH55-8) }\end{array}$ \\
\hline
\end{tabular}

All antibodies are IgM/k except $\mathrm{H} 17-1\left(\operatorname{IgG}_{3} / \mathrm{k}\right)$ and $\mathrm{CH} 24-10\left(\mathrm{IgG}_{1} / \mathrm{k}\right)$. In parentheses, the number of fusions from which the hybridomas were obtained. 

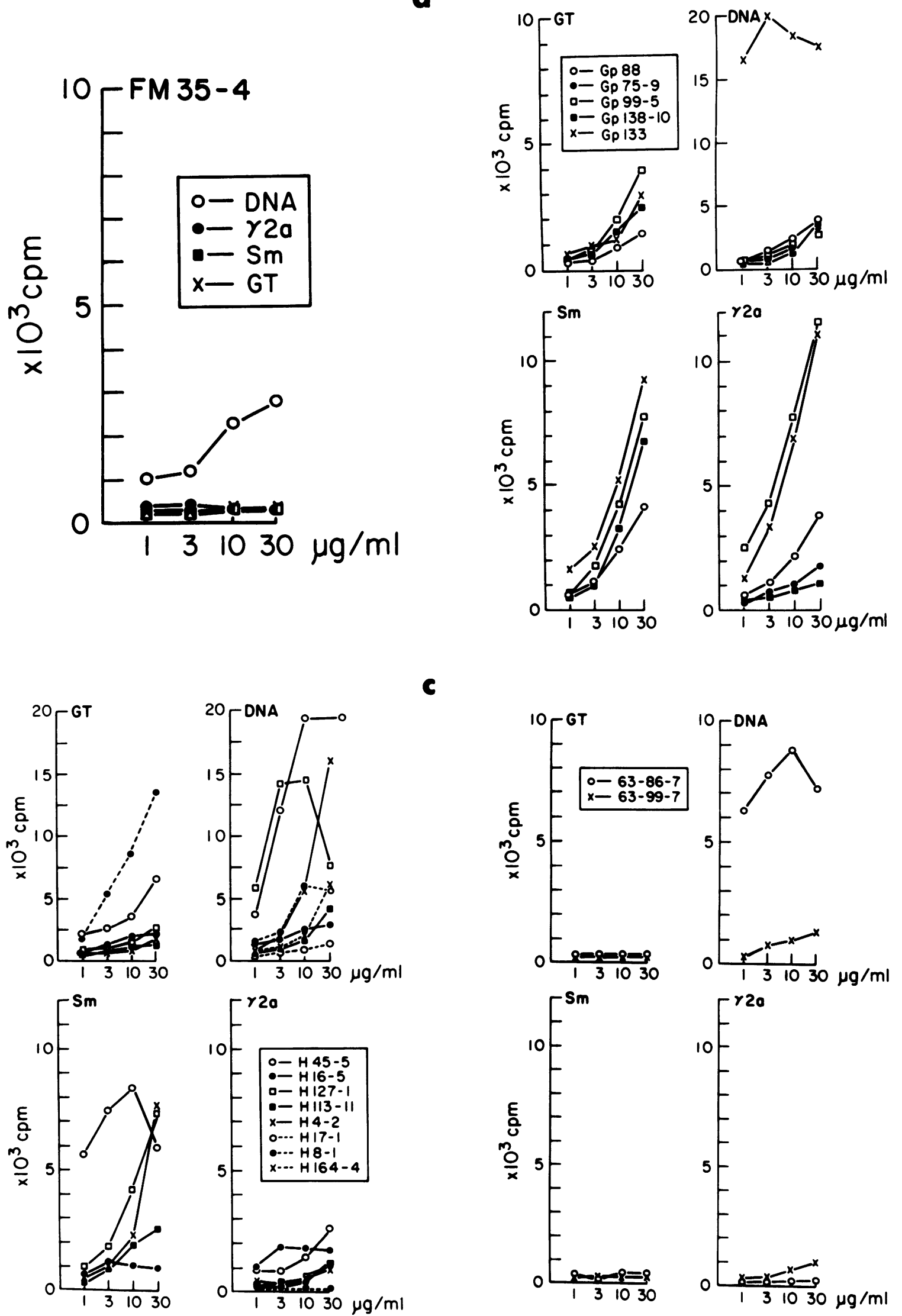

Figure 2. Dose-effect binding of various concentrations of MRL/lpr MAbs in solid phase RIA. 

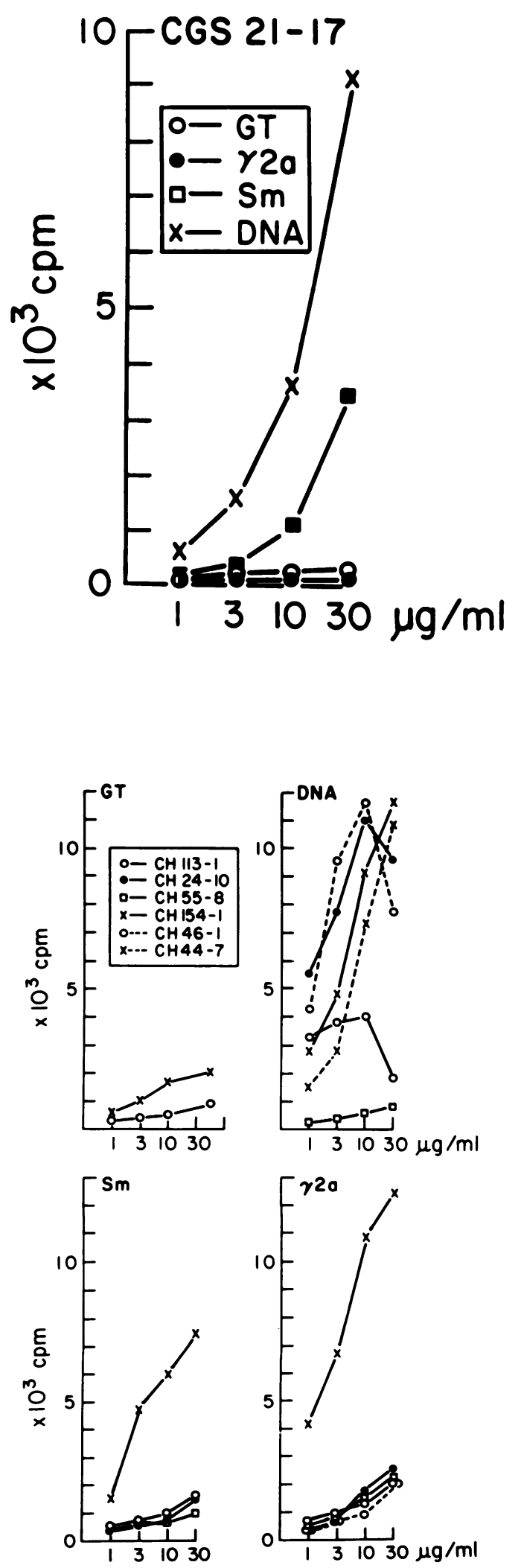

Figure 3. Dose-effect binding of various concentrations of $\mathrm{C}_{3} \mathrm{H} / \mathrm{HeJ}$ MAbs in solid-phase RIA.

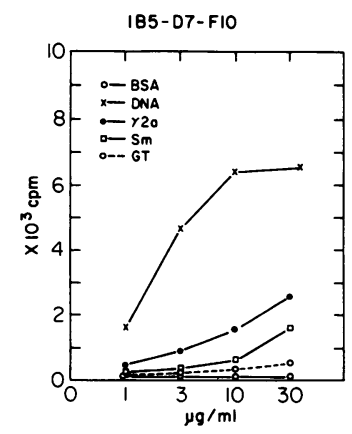

Figure 4. Dose-effect binding of various concentrations of IB5-D7-F10 MAb to various antigens.

to GT (25). Similarly, it was demonstrated that Y2IdX is shared by anti-Sm antibodies (26), H130 IdX is a dominant idiotype of anti-DNA antibodies (27) and LPS10-1 is a crossreactive idiotype shared by RF MAbs and autoantibodies with other specificities (28). Therefore, it was important to determine whether or not these idiotypes were expressed on multi-

Table II. $K_{a}$ of Autoantibodies Exhibiting Binding Specificity for GT and Self-Antigens

\begin{tabular}{|c|c|c|}
\hline Antibody & Antigens & $K_{2}$ \\
\hline GP138-10 & $\begin{array}{l}\text { GT } \\
\text { DNA } \\
\text { Sm } \\
\text { G2a }\end{array}$ & $\begin{array}{l}3.68 \times 10^{7} \\
2.42 \times 10^{6} \\
2.56 \times 10^{6} \\
3.84 \times 10^{6}\end{array}$ \\
\hline GP99-5 & $\begin{array}{l}\text { GT } \\
\text { DNA } \\
\text { Sm } \\
\text { G2a }\end{array}$ & $\begin{array}{r}1.66 \times 10^{7} \\
2.61 \times 10^{6} \\
3.0 \times 10^{7} \\
2.15 \times 10^{6}\end{array}$ \\
\hline GP88 & $\begin{array}{l}\text { GT } \\
\text { DNA } \\
\text { Sm } \\
\text { G2a }\end{array}$ & $\begin{array}{r}3.0 \times 10^{6} \\
1.0 \times 10^{6} \\
2.70 \times 10^{7} \\
8.95 \times 10^{6}\end{array}$ \\
\hline GP133 & $\begin{array}{l}\text { GT } \\
\text { DNA } \\
\text { Sm } \\
\text { G2a }\end{array}$ & $\begin{array}{r}6.80 \times 10^{6} \\
1.0 \times 10^{7} \\
1.50 \times 10^{7} \\
2.93 \times 10^{7}\end{array}$ \\
\hline H8-1 & $\begin{array}{l}\text { GT } \\
\text { DNA }\end{array}$ & $\begin{array}{l}4.46 \times 10^{7} \\
5.90 \times 10^{6}\end{array}$ \\
\hline H17-1 & DNA & $2.86 \times 10^{6}$ \\
\hline H16-5 & $\begin{array}{l}\text { GT } \\
\text { DNA } \\
\text { G2a }\end{array}$ & $\begin{array}{l}1.13 \times 10^{6} \\
2.47 \times 10^{7} \\
1.41 \times 10^{7}\end{array}$ \\
\hline H4-2 & $\begin{array}{l}\text { GT } \\
\text { DNA } \\
\text { Sm } \\
\text { G2a }\end{array}$ & $\begin{array}{l}9.75 \times 10^{7} \\
1.06 \times 10^{7} \\
1.52 \times 10^{6} \\
2.08 \times 10^{6}\end{array}$ \\
\hline H45-5 & $\begin{array}{l}\text { GT } \\
\text { DNA } \\
\text { Sm } \\
\text { G2a }\end{array}$ & $\begin{array}{l}1.27 \times 10^{7} \\
4.67 \times 10^{6} \\
1.33 \times 10^{6} \\
1.68 \times 10^{6}\end{array}$ \\
\hline H113-1 & $\begin{array}{l}\text { GT } \\
\text { DNA } \\
\text { G2a }\end{array}$ & $\begin{array}{l}9.50 \times 10^{6} \\
7.01 \times 10^{6} \\
1.13 \times 10^{6}\end{array}$ \\
\hline
\end{tabular}


Table III. Expression of G5IDX on MAbs Produced by MRL/lpr and $\mathrm{C}_{3} \mathrm{H} / \mathrm{HeJ} \mathrm{Hybridomas}$

\begin{tabular}{lc}
\hline BSA & $369 \pm(100)^{*}$ \\
G5 & $15,784 \pm(1,558)$ \\
FM35-4 & $459 \pm(101)$ \\
GP75-9 & $309 \pm(15)$ \\
GP138-10 & $321 \pm(25)$ \\
GP99-5 & $149 \pm(15)$ \\
GP88 & $1,921 \pm(50)$ \\
GP133 & $269 \pm(53)$ \\
GS13-1 & $164 \pm(94)$ \\
GS11-1 & $277 \pm(102)$ \\
GS4-1 & $170 \pm(26)$ \\
H16-5 & $4,070 \pm(448)$ \\
H4-2 & $471 \pm(21)$ \\
H17-1 & $240 \pm(18)$ \\
H45-5 & $1,694 \pm(136)$ \\
H129-1 & $2,615 \pm(409)$ \\
H113-11 & $3,452 \pm(226)$ \\
H164-4 & $2,530 \pm(145)$ \\
$63-99-7$ & $197 \pm(16)$ \\
$63-86-7$ & $163 \pm(9)$ \\
CH24-10 & $311 \pm(188)$ \\
CH154-1 & $248 \pm(8)$ \\
CH113-1 & $188 \pm(11)$ \\
CH558 & $181 \pm(44)$ \\
CH46-1 & $234 \pm(71)$ \\
CH44-7 & $158 \pm(11)$ \\
\end{tabular}

* Counts per minute average of triplicate $( \pm \mathrm{SD})$.

specific antibodies obtained from MRL and $\mathrm{C}_{3} \mathrm{H} / \mathrm{HeJ}$ mice. The expression of IdX was determined by competitive inhibition RIA as described in material and methods. Data depicted in Table III show the expression of G5IdX determined by a sensitive sandwich assay. One antibody from the GP series and five antibodies from the $\mathrm{H}$ series prepared from MRL/lpr mice expressed G5IdX. Because it is known that this IdX is expressed on a majority of anti-GAT antibodies (interstrain IdX) (25), our results indicate that the clones producing multispecific antibodies activated by GT or $\mathrm{Ab} 2 \beta$ represent a subset of the available GT repertoire.

Furthermore, the data presented in Table IV show that among 24 antibodies obtained from MRL/lpr and $\mathrm{C}_{3} \mathrm{H} / \mathrm{HeJ}$ mice immunized with GT or HP20, two share Y2IdX, three share the H130 IdX, and eight share the LPS10IdX.

(e) Study of the expression of Lyl gene. There is plentiful evidence suggesting that the Ly1B subset is involved in the production of autoantibodies (16). Because it is difficult to visualize by immunofluorescence the presence of Lyl antigens on hybridomas, we used molecular techniques to identify the expression of Lyl gene in our panel of hybridomas producing autoantibodies.

In a previous study, we demonstrated that although hybridomas producing autoantibodies obtained from strains prone to autoimmunity (NZB, mev, and MRL/lpr) failed to stain with anti-Ly1 MAbs, Ly1 genes are expressed showing two transcripts of 2.9 and $1.6 \mathrm{~kb}$. Thymocytes and two $\mathrm{CH}$ lymphoma
Table IV. Expression of Cross-Reactive Idiotypes of Anti-DNA (H130), Anti-Sm (Y2), and RF (LPS10) on Autoantibodies Obtained from $M R L / l p r$ and $C_{3} \mathrm{H} / \mathrm{HeJ}$ Mice

\begin{tabular}{|c|c|c|c|}
\hline \multirow{2}{*}{$\begin{array}{l}\text { Designation } \\
\text { of antibodies }\end{array}$} & \multicolumn{3}{|c|}{ Cross-reactive idiotypes } \\
\hline & H130 & LPS10 & Y2 \\
\hline & & $n g$ & \\
\hline FM35-4 & $*$ & & \\
\hline \multicolumn{4}{|l|}{ GP88 } \\
\hline GP138-10 & & 500 & \\
\hline GP99-5 & $150^{\ddagger}$ & 500 & \\
\hline \multicolumn{4}{|l|}{ GP75-9 } \\
\hline GP133 & & 50 & \\
\hline \multicolumn{4}{|l|}{ GS4-1 } \\
\hline \multicolumn{4}{|l|}{ GP11-1 } \\
\hline GS13-1 & & 50 & \\
\hline $\mathrm{H} 45-5$ & 150 & 50 & \\
\hline H16-5 & & 50 & \\
\hline \multicolumn{4}{|l|}{ H127-1 } \\
\hline H164-4 & 150 & & 250 \\
\hline \multicolumn{4}{|l|}{ H17-1 } \\
\hline \multicolumn{4}{|l|}{ H113-1 } \\
\hline H4-2 & & 500 & \\
\hline \multicolumn{4}{|l|}{ H8-1 } \\
\hline \multicolumn{4}{|l|}{ H81-16 } \\
\hline \multicolumn{4}{|l|}{$63-88-77$} \\
\hline \multicolumn{4}{|l|}{$63-99-7$} \\
\hline CGS21-17 & & & 250 \\
\hline \multicolumn{4}{|l|}{ CH154-1 } \\
\hline \multicolumn{4}{|l|}{ CH46-1 } \\
\hline \multicolumn{4}{|l|}{ CH55-8 } \\
\hline \multicolumn{4}{|l|}{ CH24-10 } \\
\hline \multicolumn{4}{|l|}{$\mathrm{CH} 44-7$} \\
\hline CH113-1 & & & 50 \\
\hline \multicolumn{4}{|l|}{ H130 } \\
\hline LPS 10 & & 50 & \\
\hline Y2 & & & 25 \\
\hline G5 & & & \\
\hline
\end{tabular}

* Less than $25 \%$ in inhibition with 500 ng.

‡ Amount of antibody giving $50 \%$ inhibition.

lines that were stained with anti-Lyl expressed two species of Ly1. mRNA (2.9 and $2.1 \mathrm{~kb}$ ). Although the $2.9-\mathrm{kb}$ transcript thus appears to be a precursor message, the $2.1-\mathrm{kb}$ transcript found in thymocytes represents the mature transcript encoding the 70-kD Ly1 antigen. An S1 nuclease protection assay in a preliminary experiment carried out with the complete DNA probe and RNA from thymus, $\mathrm{CH}$ lymphoma, and two hybridomas producing $1.6 \mathrm{~kb}$. Lyl message suggest that the 1.6kb band represents a truncated transcript (Mayer, R., V. Fidanza, Ch. Sidman, G. Haughton, L. Herzenberg, and C. Bona, manuscript in preparation).

20 hybridomas from MRL and $\mathrm{C}_{3} \mathrm{H}$ mice were studied in Northern blotting for the expression of Lyl gene. Only five hybridomas obtained from MRL/lpr mice (FM35-6, GP99-5, GP133, GS11-1, and H91-12) and one from $\mathrm{C}_{3} \mathrm{H} / \mathrm{HeJ}$ mice 


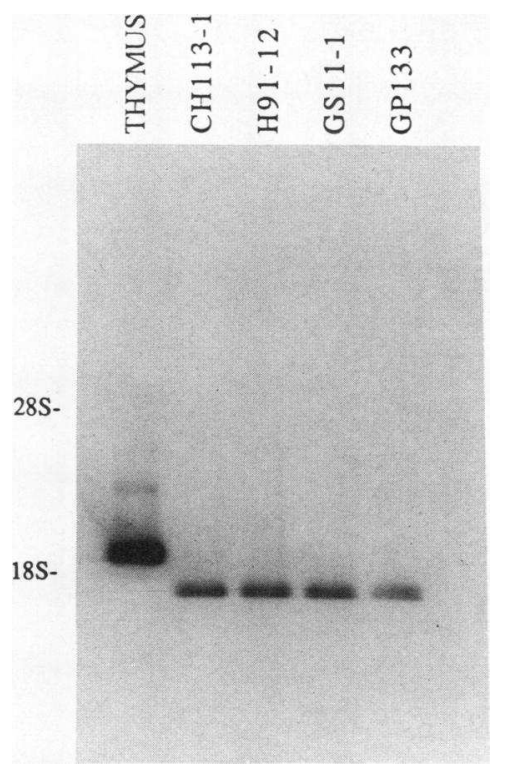

Figure 5. Northern blot of RNA extracted from thymus, MRL/lpr, and $\mathrm{C}_{3} \mathrm{H} / \mathrm{HeJ}$ hybridomas. Blot was hybridized with Ly1-cDNA probe (7-d exposure).
(CH113-1) have a 1.6-kb .Ly1 transcript (Fig. 5). The results show that only a small fraction of multispecific antibodies described in this study probably belong to Ly1.B subset.

$(f)$ Characteristics of $V$ gene families used by multispecific antibodies. Expression of four IdXs on only a fraction of multispecific antibodies indicated that they are produced by a heterogenous population of clones activated subsequent to immunization with GT or HP20. To strengthen this conclusion, we proceeded to analyze $V_{H}$ and $V_{K}$ gene families from which the rearranged $\mathrm{V}$ genes encoding multispecific antibodies are derived. Fig. 6 illustrates an example of Northern blotting analysis in which the RNA was probed with $V_{H}$ probes. The data presented show that with the exception of two antibodies that used $V_{H} J 606$ genes, all other antibodies used J558 and $3^{\prime} V_{H}$ gene families.

6 out of 27 hybridoma RNA did not hybridize with our panel of $V_{K}$ probes, each a prototype of $11 V_{K}$ families.

$A$ random usage of $11 V_{K}$ families was noted in the remaining 21 hybridomas. Note also that five hybridomas used

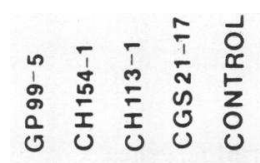

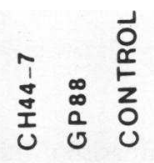

$\begin{array}{lll} & & 0 \\ 0 & - & x \\ 0 & \frac{1}{5} & z \\ 0 & \bar{n} & 0 \\ 0 & 0 & 0\end{array}$

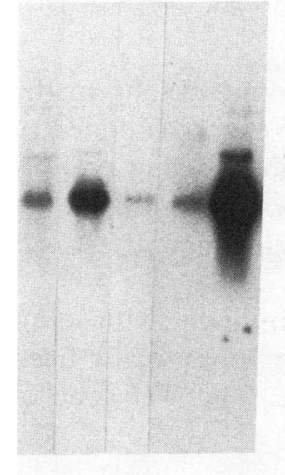

7183

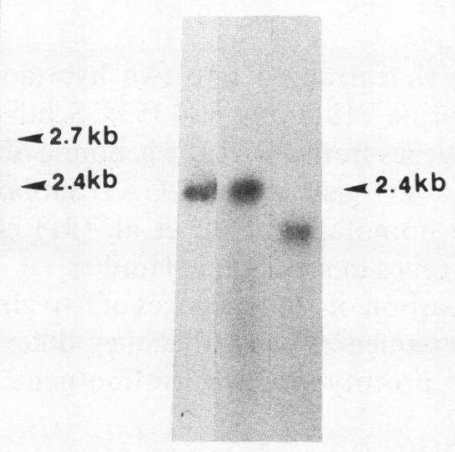

QPC52

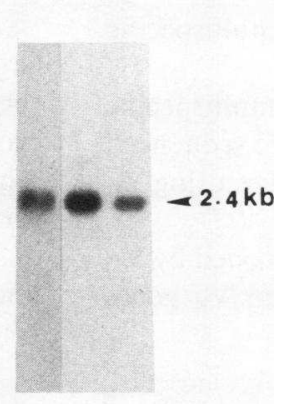

5606
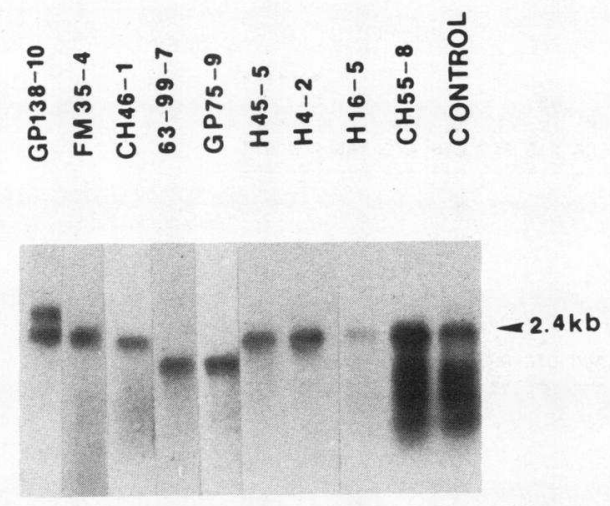

J 558

s 107

Figure 6. Northern blot analysis of RNA extracted from MRL and $\mathrm{C}_{3} \mathrm{H} / \mathrm{HeJ}$ hybridomas, hybridized with VH7183, QPC52, J606, J558, and S107 probes. RNA extracted from the following cell lines were used as controls: $129-48$ for $V_{H} 7183$, ID10 for $V_{H} Q P C 52, J 606$ for $V_{H} J 606$, $\mathrm{H} 130$ for $\mathrm{V}_{\mathrm{H}} \mathrm{J} 558$, and HOPC8 for $\mathrm{V}_{\mathrm{H}} \mathrm{S} 107$. 


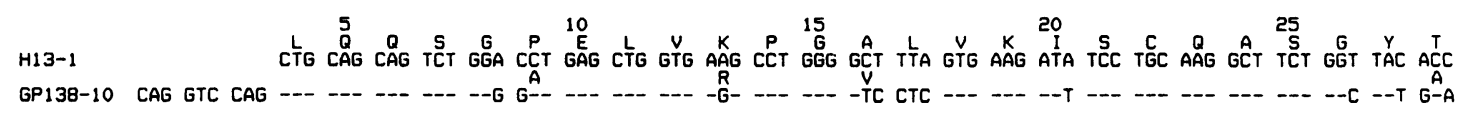

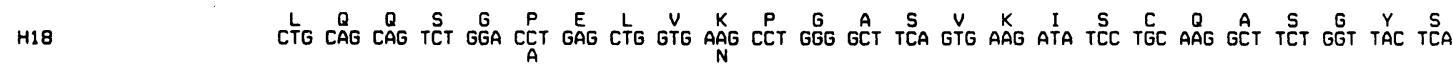
H45-5 CAG -.- -.-

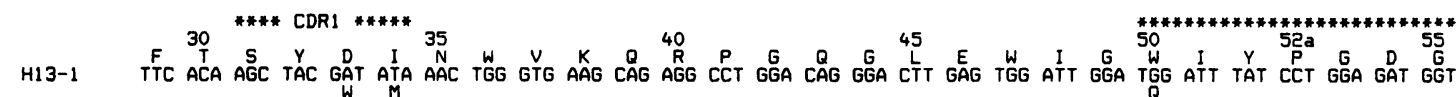
GP138-10 -- --T -- -- TGG

H18 TTT ACT GGC TAC $\underset{N}{Y}$ TT ATG AAC TGG GTG ATG CAAG AGC CAT GGG $\underset{K}{M}$ AAG AGC CIT GAGG TGGG ATT GGA CATT ATT AAT CCT TAC AAT GGT H45-5 --C -- -- -- $A$ AAC -- --

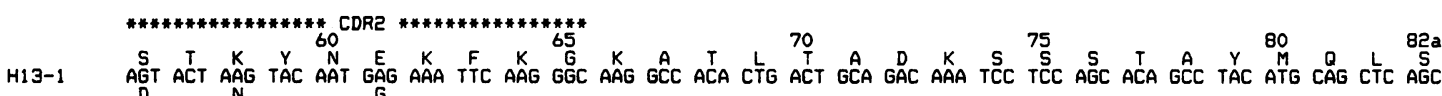
GP138-10 GA-

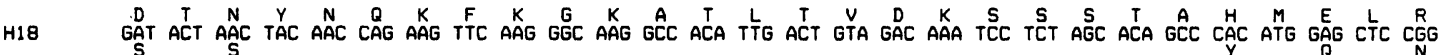
H18 GAT ACT AAC TAC AAC CAG AAG TTC AAG GGC AAG GCC ACA TTG ACT GTA GAC AAA TCC TCT AGC ACA GCC CAC ATG GAG CTC CGG
H45-5 AG

H13-1 AGC CITG ACT TCT GAG ANC TCT GCA G

H13-1 AGC CTG ACT TCT GAG AAC TCT GCA G
GP138-10 -- --A --A -- -- G

H18 AGC CITG GCA TCT GAE GAC TCST GCA G

H45-5 -5 TAT TAC TGT GCA AGA TAT AGT TAC NAN GCC (FLIGG

Figure 7. Nucleotide sequence of VH genes expressed in GP138-10 and H45-5 hybridomas. Comparison with GAT-VH germline genes.

$\mathrm{V}_{\mathrm{K}} 22$ and $\mathrm{VK} 24$ genes, which are rarely used in multispecific antibodies (30).

To study the relatedness of $\mathrm{V}$ genes coding for multispecific antibodies to those coding for GT specificities, we sequenced the $V_{H}$ and $V_{K}$ genes of two multispecific antibodies using $V_{H}$ J558 genes.

It was reported that anti-GT antibodies are encoded by $V_{H}$ genes derived from the $V_{H} J 558$ family (31) and $V_{K}$ genes derived from the $V_{K} 1$ family (32).
The VH rearranged into two hybridomas belong to the largest murine VH family, VH J558. Schiff et al. (4) isolated 19 germline genes from a BALB/c genomic library using a cDNA probe of a VH gene used by GAT antibodies. Based on the sequence homology, Schiff et al. (31) classified VH GAT germline genes in subdiscrete families.

Comparison of the sequences of two antibodies with germline gene sequences show that they differ substantially from $\mathrm{H} 10$, the prototype GT germline gene. The VH gene of

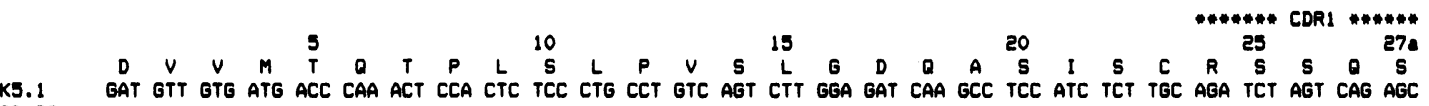
GP138-10

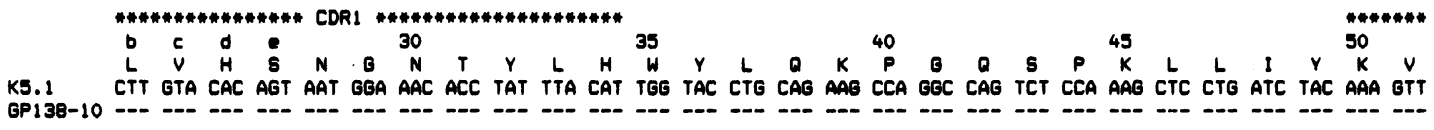

\section{***** CDR2 *******}

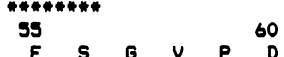

D $\quad 65$ TS 70 K5.1 TCC AAC CGA TTT TCT BGO GTC CCA GAC AGG TTC AGT GEC AGT GGA TCA GGG ACA GAT TTC ACA CTC AAG ATC GAC AGA GTG GAG

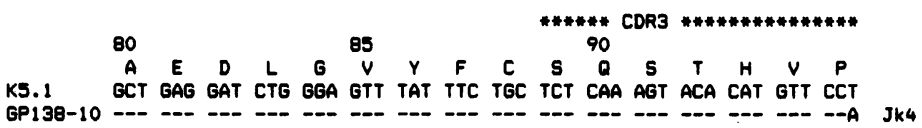

Figure 8. Nucleotide sequence of VK gene expressed in GP138-10 hybridomas comparison with K5.1 GAT-VK1 germline gene. 


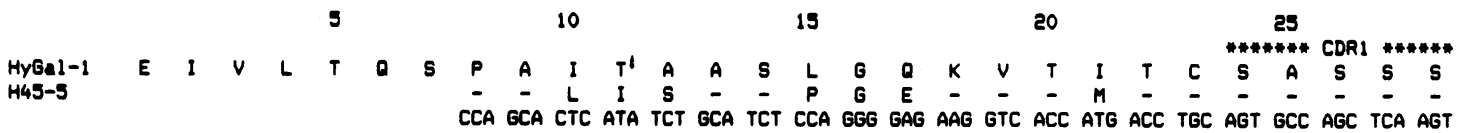

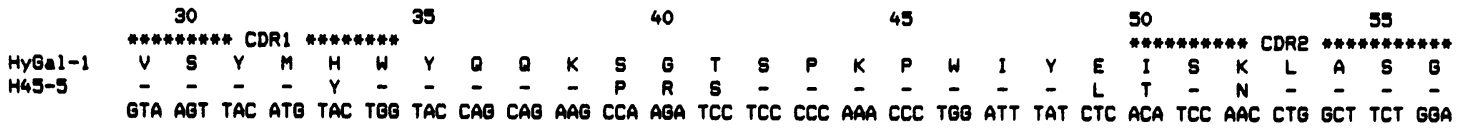

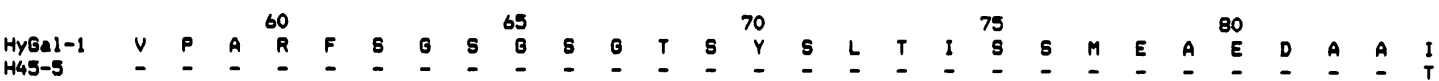

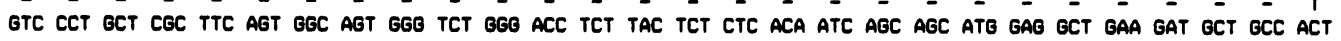

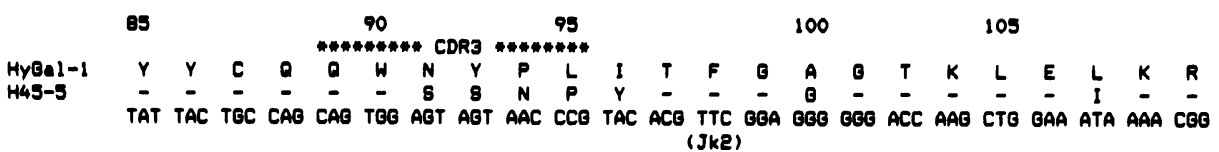

Figure 9. Nucleotide and amino acid translated sequence of H45-5 hybridomas. Comparison with amino acid sequence of HyGAL-1.

GP138-10 shows highest homology with H13-1 (an anti-GAT germline gene). Two replacement mutations were observed in CDR1, four in CDR2 and six in framework segments. The VH gene is associated with a D segment corresponding to SP2.3 gene and unmutated JH2. H45-5 shows the highest homology with $\mathrm{H} 18$ (anti-GAT germline gene): one replacement mutation was noted in CDR1, four were noted in CDR2, and nine were noted in the framework segments. The VH gene of this antibody is associated with a $\mathrm{D}$ segment corresponding to FL16.1 gene and JH3 (Fig. 7).

These data show that VH genes of these two multispecific antibodies are derived from different GAT VH germline gene subfamilies and are associated with different $\mathrm{D}$ and $\mathrm{JH}$ gene segments.

The majority of VK genes used by anti-GAT antibodies are derived from VK1 subfamily (32). The data depicted in Fig. 8 show that GP138-10 expresses an identical sequence with $\mathrm{K} 5-1$, one of the VK germline gene cloned from a BALB/c genomic library by using a VK GAT-specific probe. By contrast, H45-5 uses a VK gene showing highest homology with HyGAL-1 (VK4). Because VK HyGAL-1 is an amino acid sequence (23), we used the translated protein sequence of H45-5 for comparison. VK H45-5 shows one replacement mutation in CDR1 and two in CDR2 and four in CDR3 compared with HyGAL-1. Three replacement mutations around 15 and 40 were residues in frameworks 1 and 2 . VK sequence of this antibody is associated with JK2 like HyGAL-1 (Fig. 9). These data clearly show that the clones producing multispecific antibodies expanded subsequent to immunization with GT or HP20 anti-Id antibodies, use the same V genes related to GAT antibodies as well as completely unrelated genes like VK gene used by H45-5 MAb.

\section{Discussion}

There is increased evidence demonstrating that the immune repertoire of normal animals and of animals prone to autoim- mune disease contains clones bearing Ig receptors able to bind both self- and foreign antigens $(1,2,7)$. This degeneracy of the receptor can have important implications on understanding the onset of autoimmune disease because there are only a few examples demonstrating the expansion of autoreactive clones by autoantigens.

If the affinity of binding of self- and foreign antigens to $\mathrm{Ig}$ receptor of such clones is similar, it may be envisioned that the proliferation of autoreactive clones can be triggered by foreign antigens. Alternatively, we hypothesized that the autoreactive clones can be also activated by anti-Id antibodies mimicking the self or foreign antigens (34).

In this communication, we present results demonstrating that immunization with GT in CFA or with an anti-Id MAb carrying the internal image of GT expanded clones producing antibodies specific for GT and three self-antigens tested. The synthesis of RF is not surprising because it was previously shown that the conventional responses elicited by TI or TD antigens is associated with the synthesis of $\mathrm{RF}_{5}$ in both normal animals $(22,23)$ and in healthy human subjects $(35)$. However, the appearance of anti-DNA and Sm antibodies in 1-mo-old MRL/lpr and of anti-Sm antibodies in $\mathrm{C}_{3} \mathrm{H} / \mathrm{HeJ}$ immunized with $\mathrm{GT}$ or $\mathrm{Ab} 2 \beta$ is quite surprising because no increased levels of anti-DNA or Sm antibodies were observed when the mice were injected with saline, or with an irrelevant $A b 2 \beta$ or CFA. Because of the polyclonal nature of serum antibodies, which does not permit us to determine whether the anti-self antibodies are produced by clones activated by GT and Ab2 $\beta$ or are produced by other clones, we prepared hybridomas from $\mathrm{MRL} / \mathrm{lpr}$ and $\mathrm{C}_{3} \mathrm{H} / \mathrm{HeJ}$ mice immunized with various antigens.

Hybridomas producing antibodies specific for GT were obtained from both MRL/lpr and $\mathrm{C}_{3} \mathrm{H} / \mathrm{HeJ}$, whereas those producing multispecific antibodies were obtained only from MRL/lpr.

It should be mentioned that only two antibodies obtained from the secondary $\mathrm{GT}$ response exhibited multispecific binding properties suggesting that the clones expanded by foreign 
Table V. Summary Results: Origin of Antibodies, Antigen Binding, Idiotype Expression, and V Gene Usage

\begin{tabular}{|c|c|c|c|c|c|c|c|c|}
\hline \multirow[b]{2}{*}{ Origin of hybridomas } & \multirow[b]{2}{*}{ Designation } & \multirow[b]{2}{*}{ Antigen binding } & \multicolumn{4}{|c|}{ Idiotype expression } & \multicolumn{2}{|c|}{ V Gene expression } \\
\hline & & & G5 & H-130 & LPS 10 & Y2 & $\mathbf{V}_{\mathbf{H}}$ & $\mathbf{v}_{\mathbf{k}}$ \\
\hline MRL Inj. CFA & FM35-4 & DNA & & & & & $\mathrm{J} 558$ & 4 \\
\hline MRL immunized & GP75-9 & DNA, G2a & & & & & $\mathrm{J} 558$ & 8 \\
\hline $1 \times \mathbf{G T}$ & GP138-10 & GT, DNA, Sm, G2a & & & + & & J558 & 1 \\
\hline \multirow[t]{3}{*}{ (Primary) } & GP99-5 & GT, DNA, Sm, G2a & & + & + & & 7.183 & 1 \\
\hline & GP88 & GT, DNA, Sm, G2a & + & & & & QPC52 & 9 \\
\hline & GP133 & GT, DNA, Sm, G2a & & & + & & J606 & 1 \\
\hline MRL immunized & GS 13-1 & Sticky & & & + & & S107 & 1 \\
\hline $2 \times \mathrm{GT}$ & GS $11-1$ & GT, DNA, Sm, G2a & & & & & J606 & 10 \\
\hline Secondary & GS 4-1 & GT, DNA, Sm, G2a & & & & & $\mathrm{J} 558$ & 1 \\
\hline MRL immunized & H16-5 & GT, DNA, Sm, G2a & + & & + & & J558 & NI \\
\hline \multirow[t]{8}{*}{$3 \times$ HP20 } & $\mathrm{H} 4-2$ & GT, DNA, Sm, G2a & & & + & & J558 & 9 \\
\hline & H17-1 & DNA & & & & & QPC52 & 22 \\
\hline & H45-5 & GT, DNA, Sm, G2a & + & + & + & & J558 & 4 \\
\hline & H127-1 & GT, DNA, Sm, G2a & + & & & & QPC52 & 4 \\
\hline & H8-1 & GT, DNA & ND & & & & NI & NI \\
\hline & H113-11 & GT, DNA, Sm, G2a & + & & & & QPC52 & 24 \\
\hline & H164-4 & GT, DNA & + & + & & + & QPC52 & $\mathrm{NI}$ \\
\hline & H91-16 & $\mathrm{GT}, \mathrm{G} 2 \mathrm{a}$ & ND & & & & QPC52 & 8 \\
\hline MRL immunized & $63-99-7$ & DNA, G2a & & & & & $\mathrm{J} 558$ & 10 \\
\hline $3 \times 63-4$ & $63-86-7$ & DNA & & & & & $\mathrm{J} 558$ & 4 \\
\hline $\begin{array}{l}\mathrm{C}_{3} \mathrm{H} \text { immunized } \\
2 \times \mathrm{GT}\end{array}$ & CGS21-17 & DNA, G2a & ND & & & + & 7183 & NI \\
\hline $\mathrm{C}_{3} \mathrm{H}$ immunized & $\mathrm{CH} 24-10$ & DNA, Sm, G2a & & & & & $\mathrm{J} 558$ & 22 \\
\hline \multirow[t]{5}{*}{$3 \times$ HP20 } & CH154-1 & GT, DNA, Sm, G2a & & & & & 7183 & 10 \\
\hline & CH113-1 & GT, DNA, Sm, G2a & & & & + & 7183 & $\mathrm{NI}$ \\
\hline & CH55-8 & DNA, Sm, G2a & & & & & J558 & NI \\
\hline & CH46-1 & DNA, G2a & & & & & J558 & 22 \\
\hline & CH44-7 & DNA & & & & & QPC52 & 19 \\
\hline
\end{tabular}

NI, not identified.

antigen from the memory pool are devoid of self-reactivity. These data are in agreement with those reported by Naparstek et al. (2), who showed that only primary anti-arsonate antibodies exhibit self-binding properties. The immunization with Ab2 $\beta$ carrying the internal image of the GT elicited the expansion of multispecific antibodies producing clones in both strains with a higher frequency in MRL/lpr. This is not surprising because the proportion of precursors of self-reactive clones is an important component of the preimmune repertoire and is probably higher in the strains prone to autoimmunity even before the onset of the disease. Actually, it is known that the strains prone to autoimmune disease exhibit an accelerated maturation of the immune system compared to normal strains.

Our observations strongly support the idea that the clones immortalized as hybridomas from animals immunized with HP20 have been expanded by virtue of GT molecular mimicry by Ab2 $\beta$ HP20. First, no GT-specific or multireactive antibodies have been obtained from MRL/lpr mice immunized three times in saline with 63-4 an anti-Id MAb specific for the IdI of an antibody reactive with PR8 influenza virus hemagglutinin. Second, an MAb obtained from BALB/c mice immunized with a synthetic peptide corresponding to the $D$ segment of
HP20 that carries the internal image of the antigen exhibits multispecific binding properties.

It should be mentioned that affinity measurements of antibodies obtained from hybridomas prepared from MRL/lpr mice immunized with GT or HP20 indicate that they are roughly similar to self- and foreign antigens. Together, these results suggest that $\mathrm{GT}$ or $\mathrm{Ab} 2 \beta$ carrying the internal image of GT can activate clones that produce antibodies with a similar affinity for self-antigens. Analysis of the expression of G5Id of anti-GAT antibodies showed that one of five GT primary MAb and five of eight from HP20 immunized animals expressed this idiotype. This frequency is expected from our early prediction that, whereas $\mathrm{Ab} 2 \alpha$ specific for regulatory idiotopes expand mainly $\mathrm{Ag}^{+} \mathrm{Id}^{+}$clones, the $\mathrm{Ab} 2 \alpha$ by virtue of mimicry of the antigens stimulate the expansion of both $\mathrm{Ag}^{+}$ $\mathrm{Id}^{+}$and $\mathrm{Ag}^{+} \mathrm{Id}^{-}$clones (36). This is also strongly supported by previous data demonstrating that the injection of HP20 induces $\mathrm{Id}+\mathrm{Ag}-$ antibodies and that the $\mathrm{D}$ region of these antibodies plays an important role in antigen recognition (38).

The analysis of the expression of IdX of autoantibodies clearly indicate that the set of clones producing multispecific antibodies is made up of a heterogenous population. Three MAb share H130IdX of anti-DNA antibodies, two share 
Y2IdX of anti-Sm antibodies, and eight share the LPS-10 IdX of a monoclonal RF widely expressed in autoantibodies with various specificities (37). Because it was shown that GAT antibodies, exhibiting high affinity for GT determinants, are encoded by $\mathrm{V}$ genes deriving from a few germline genes of $V_{H}$ J558 family $\left(V_{H}\right)$ and two germline genes from $V_{K} I$ family we have studied $\mathrm{V}$ genes usage in our set of multispecific antibodies.

This study clearly shows that multispecific antibodies are encoded by various $V_{H}$ and $V_{K}$ families, data in agreement with idiotypic analysis indicating a clonal heterogeneity.

It should be mentioned that an overrepresentation of $V_{H}$ J558 and $3^{\prime}$ and $V_{H}$ families was observed in our panel of multispecific antibodies, similar to those observed by us and others in the case of autoantibodies with other specificities (37-40). In contrast, in the case of $V_{K}$ families we did not observe a biased usage of $V_{K} 1, V_{K} 4, V_{K} 10$, and $V_{K} 19$ characteristics of autoantibodies (30). Some $V_{K}$ families such as $V_{K} 22$ and $\mathrm{V}_{\mathrm{K}} 24$ rarely used by other autoantibodies, were used by five multispecific antibodies that also bound to DNA. The ability to form similar combining sites by $\mathrm{V}$ genes from various families is also supported by data reported by Akoklar et al. (42) who showed that several antibodies specific for $\alpha(1-6)$ dextran derive their $\mathrm{V}$ genes from various families.

These results summarized in Table $\mathrm{V}$ strongly suggest that the clones producing multispecific antibodies that have been expanded by GT, Ab2 $\beta$ carrying the internal image of GT or synthetic peptide corresponding to $\mathrm{D}$ segment of $\mathrm{Ab} 2 \beta$, do not belong to conventional subset of GT precursors.

To substantiate this conclusion we sequenced the $\mathrm{V}$ genes of two hybridomas producing multispecific antibodies and that, like GT antibodies, are encoded by $V_{H}$ genes from $V_{H}$ J558 family. A few amino acid substitutions were observed in CDRs and framework segments when their sequences were compared with H13-1 and H-18 germline genes used by antiGAT antibodies. One antibody GP138-10 uses a VK gene identical to K5-1 germline gene used by anti-GAT antibodies. This would suggest that the six mutations observed in two CDRs of VH and/or D segment are responsible for the binding of GP138-10 to self-antigens in addition to GT. The VH of $\mathrm{H} 45-5$ gene derived from $\mathrm{H}-18$ germline gene is associated with a VK4 light chain gene used by clones producing anti- $\beta 1-6$ galactan antibodies (33), strongly supporting the idea that clones producing antibodies binding to GT and self-antigens could originate from a subset different from GT-antibody cell precursors.

In conclusion, our data demonstrate that B cell clones producing antibodies able to interact with a similar affinity constant with a foreign and self-antigens may be expanded by the foreign antigen or an anti-Id antibody carrying the internal image of the foreign antigens. It appears therefore, that autoreactive clones can be activated by foreign antigens or anti-Id antibodies produced in the response to immunizations or infections and that such autoantibodies could be involved in the pathogenesis of autoimmune diseases.

\section{Acknowledgments}

This work was supported by grant 2902 from the Council for Tobacco Research USA, Inc. and grant IP01-A124671-01 from the National Institutes of Health.

\section{References}

1. Kabat, E. A., K. G. Nickerson, J. Liao, L. Grossbard, E. F. Osserman, E. Glickman, L. Chess, J. B. Robbins, R. Schneerson, and Y. Yasig. 1986. A human monoclonal macroglobulin with specificity for $\alpha(2-8)$ linked poly-N acetyl. neuraminic acid, the capsular which crossreacts with polynucleotides and with denaturated DNA. J. Exp. Med. 164:642-656.

2. Naparstek, Y., J. André-Schwartz, T. Manser, L. J. Wysocki, L. Breitman, B. D. Stollar, M. Gefter, and R. S. Schwartz. 1986. A single germline $V_{H}$ gene segment of normal $A / J$ mice encodes autoantibodies characteristic of system lupus erythematosus. J. Exp. Med. 164:614626.

3. Zabriskie, J. B., K. C. Hsu, and B. C. Segal. 1970. Heart reactive antibody associated with rheumatic fever: characterization and diagnostic significance. Clin. Exp. Immunol. 7:147-154.

4. Husby, G., I. van de Rijn, J. B. Zabriskie, Z. H. Abdin, and R. C. Williams. 1970. Antibodies reacting with cytoplasm of subthalamic and caudate nuclei neurons on chorea and acute rheumatic fever. $J$. Exp. Med. 144:1094-1099.

5. Zabriskie, J. B., and E. H. Freimer. 1966. An immunological relationship between the group A streptococcus and mammalian muscle. J. Exp. Med. 124:661-672.

6. Ayakawa, G. Y., A. S. Bleiweis, P. J. Crowley, and M. W. Cunningham. 1988. Heart cross-reactive antigens of mutants streptococci share epitopes with group A streptococci and myosin. J. Immunol. 140:253-257.

7. Monestier, M., B. Bonin, P. Migliorini, H. Dang, S. Datta, R. Kuppers, N. Rose, P. Maurer, N. Talal, and C. Bona. 1987. Autoantibodies of various specificities encoded by genes from the VHJ 588 family bind to foreign antigens and share idiotopes of antibodies specific for self and foreign antigens. J. Exp. Med. 166:1109-1124.

8. Benacerraf, B., J. A. Kapp, P. Debre, C. W. Pierce, and F. dela Croix. 1975. The stimulation of specific suppression $T$ cells in genetic nonresponder mice by linear random polymers of $\mathrm{L}$ amino acids. Transplant Rev. 26:21.

9. Ollier, P., J. Rocca-Serra, G. Sommé, J. Theze, and M. Fougereau. 1985. The idiotypic network and the internal image: possible regulation of a germ-line network by pauci gene encoded $A b_{a}$ antibodies in the GAT system. EMBO (Eur. Mol. Biol. Organ.) J. 4:3681.

10. Bruck, C., S. M. Co, M. Slaoui, G. N. Gaulton, T. Smith, B. N. Fields, J. I. Mullins, and M. I. Green. 1986. Nucleic acid sequence of an internal image-bearing monoclonal anti-idiotype and its comparison to the sequence of the external antigen. Proc. Natl. Acad. Sci. USA. 83:6578-6582.

11. Moran, T. M., M. Monestier, A. C. K. Lai, G. Norton, M. A. Reale, M. A. Thompson, J. L. Schulman, R. Riblet, and C. A. Bona. 1987. Characterization of variable region genes and shared cross-reactive idiotypes of antibodies specific for antigens of various influenza viruses. Viral Immunol. 1:1-12.

12. Goldberg, B., W. E. Paul, and C. A. Bona. 1983. Idiotype-antiidiotype regulation IV. Expression of common regulatory idiotopes on fructosan binding and non-fructosan binding monoclonal immunoglobulin. J. Exp. Med. 158:515-528.

13. Friguet, B., A. F. Chaffotte, L. Djavadi-Ohaniance, and M. E. Goldberg. 1985. Measurements of the true affinity constant in solution of antigen-antibody complexes by enzyme-linked immunosorbant assay. J. Immunol. Methods. 77:305-311.

14. Sharon, J., E. A. Kabat, and S. L. Morrison. 1982. Association constants of hybridomas antibodies specific for $\alpha(1-6)$ linked dextran determined by affinity electrophoresis. Mol. Immunol. 19:389-396.

15. Victor-Kobrin, C., F. A. Bonilla, B. Bellon, and C. A. Bona. 1985. Immunochemical and molecular characterization of regulatory idiotopes expressed by monoclonal antibodies exhibiting or lacking B2-6 fructosan binding activity. J. Exp. Med. 162:647-662.

16. Maniatis, T., E. F. Fritsch, and J. Sambrook. 1982. Molecular Cloning: a Laboratory Manual. Cold Spring Harbor Laboratory, Cold Spring Harbor, NY. 191-294. 
17. Painter, C. J., M. Monestier, A. Chew, A. Bona-Dimitriu, K. Kasturi, C. Bailey, V. E. Scott, Ch. L. Sidman, and C. A. Bona. 1988. Specificities and $\mathrm{V}$ genes encoding monoclonal autoantibodies from viable motheaten mice. J. Exp. Med. 167:1137-1153.

18. Huang, H.-J. S., N. H. Jones, J. L. Strominger and L. A. Herzenberg. 1987. Molecular cloning of Ly 1-1, a membrane glycoprotein of mouse T lymphocytes and a subset of B cells. Proc. Natl. Acad. Sci. USA. 84:204-208.

19. Sikder, S. K., E. A. Kabat, and S. L. Morrison. 1985. Alternative splicing patterns in an aberrantly rearranged immunoglobulin $\mathrm{K}$ light-chain gene. Proc. Natl. Acad. Sci. USA. 82:4045.

20. Sanger, F., S. Nichlen, and A. R. Coulson. 1977. DNA sequencing with chain terminating inhibitors. Proc. Natl. Acad. Sci. USA. 74:5463-5467.

21. Deveraux, J., P. Halberli, and O. Smithies. 1984. A comprehensive set of sequence analysis programs for the VAX. Nucleic Acid Res. 12:387.

22. Nemazee, D. A., and V. L. Sato. 1983. Induction of rheumatoid antibody in the mouse: regulated production of autoantibody in the secondary humoral response. J. Exp. Med. 158:529-545.

23. Manheimer, A. J., C. Victor-Kobrin, K. E. Stein, and C. A. Bona. 1984. Anti-immunoglobulin antibodies V. Age-dependent variation of clones stimulated by polysaccharide TI-2 antigens in 129 and MRL mice spontaneously producing anti- $\tau$-globulin antibodies. $J$. Immunol. 133:562-568.

24. Mazza, G., V. Guigou, D. Moinier, S. Corbet, P. Ollier, and M. Fougereau. 1987. Molecular interactions in the GAT idiotype network: an approach using synthetic peptides. Ann. Inst. Pasteur. 138:3-17.

25. Ju, S. T., D. V. Cramer, M. E. Dorf. 1979. Idiotypic analysis of anti-GAT antibodies. V. Distribution of interspecies cross-reactive idiotype. J. Immunol. 123:877-883.

26. Pisetsky, D. S., and E. A. Lerner. 1982. Idiotypic analysis of a monoclonal anti-Sm antibody. J. Immunol. 129:1489.

27. Migliorini, P., B. Ardman, J. Kaburaki, and R. S. Schwartz. 1987. Parallel sets of autoantibodies in MRL-lpr/lpr mice. An antiDNA, anti-Sm RNP, anti-gp70 network. J. Exp. Med. 165:483.

28. Monestier, M., A. Manheimer-Lory, B. Bellon, C. Painter, H. Dang, N. Talal, M. Zanetti, R. Schwartz, D. Pisetsky, R. Kuppers, N. Rose, J. Brochier, L. Klareskog, R. Holmdahl, B. Erlanger, F. Alt, and C. Bona. 1986. Shared idiotopes and restricted VH genes characterize murine autoantibodies of various specificities. J. Clin. Invest. 78:753759.

29. Hayakawa, K., R. R. Hardy, M. Honda, L. A. Herzenberg, A. D. Steinberg, and L. A. Herzenberg. 1984. Ly.1 B cells: functionally distinct lymphocytes that secrete IgM autoantibodies. Proc. Natl. Acad. Sci. USA. 81:2494.
30. Kasturi, K., M. Monestier, R. Mayer, and C. Bona. 1988. Biased usage of certain VK gene families by autoantibodies and their polymorphism in autoimmune strains. Mol. Immunol. 25:213-219.

31. Schiff, C. L., M. Milili, and M. Fougereau. 1985. Functional and pseudogenes are similarly organized and may equally contribute to the extensive antibody diversity of the $\operatorname{IgV}_{\mathrm{H}} \mathrm{II}$ family. $E M B O$ (Eur. Mol. Biol. Organ.) J. 4:1225-1230.

32. Corbet, S., M. Milili, M. Fougereau, and C. L. Schiff. 1987. Two VK germline genes related to the GAT idiotypic network account for the major subfamilies of the mouse VK-1 variability subgroup. $J$. Immunol. 138:932-939.

33. Rudikoff, S., 1984. Structural correlates of idiotypes expressed on galactan-binding antibodies. In The Biology of Idiotypes. M. I. Green and A. Nisonoff, editors. Plenum Press, New York/London. 115-130. York.

34. Bona, C. 1987. Regulatory idiotopes. John Wiley \& Sons, New

35. Welch, M. J., S. Fong, J. H. Vaugham, and D. A. Carson. 1983. Increased frequency of rheumatoid factor precursor B lymphocytes after immunization of normal adults with tetanus toxoid. Clin. Exp. Immunol. 51:299-304.

36. Bona, C., and T. Moran. 1985. Idiotype vaccines. Ann. Immunol. (Paris). 136C:299-312.

37. Painter, C., M. Monestier, B. Bonin, and C. A. Bona. 1986. Functional and Molecular studies of $\mathrm{V}$ genes expressed in autoantibodies. Immunol. Rev. 94:75-98.

38. Schiff, C., M. Milili, I. Hue, S. Rudikoff, and M. Fougereau. 1986. Genetic basis for expression of the idiotype network. J. Exp. Med. 163:573-587.

39. Souronjon, M., M. E. White-Scharf, J. André-Schwartz, M. Gefter, and R. S. Schwartz. 1989. Preferential autoantibody reactivity of the preimmune B cell repertoire in normal mice. J. Immunol. 140:4173-4179.

40. Dighiero, G., P. Lymberi, D. Holmberg, I. Lundquist, A. Coutinho, and S. Avrameas. 1985. High frequency of natural autoantibodies in normal newborn mice. J. Immunol. 134:765-771.

41. Dighiero, G., B. Guilbert, and S. Avrameas. 1982. Naturally occurring antibodies against nine common antigens in human sera. II. High incidence of monoclonal Ig exhibiting antibody activity against actin and tubulin and sharing antibody specificities with natural antibodies. J. Immunol. 128:2778-2792.

42. Akolkar, P. N., S. K. Sikder, S. B. Bhattacharya, J. Liao, F. Gruezo, S. L. Morisson, and E. Kabat. 1987. Different VL and VH germline gene are used to produce similar combining sites with specificity for $\alpha(1-6)$ dextrans. J. Immunol. 138:4472-4479. 